\title{
Analysis of Anticancer Activity and Chemical Sensitization Effects of Dendropanax morbifera and Commersonia bartramia Extracts
}

\author{
SEONGMIN KIM ${ }^{1 *}$, SUNG GYU PARK ${ }^{2,3 *}$, YOON JAE SONG $^{2}$, JEONG KOO PARK ${ }^{3}$, \\ CHEOL HEE $\mathrm{CHOI}^{4}, \mathrm{SANGHOON} \mathrm{LEE}^{1}$ and ROBERT M. HOFFMAN ${ }^{5,6}$ \\ ${ }^{1}$ Department of Obstetrics and Gynecology, Korea University College of Medicine, Seoul, Republic of Korea; \\ ${ }^{2}$ Department of Life Science, Gachon University, Seongnam, Republic of Korea; \\ ${ }^{3}$ Metabio Inc., Seoul, Republic of Korea; \\ ${ }^{4}$ Department of Pharmacology, Chosun University Medical School, Gwangju, Republic of Korea; \\ ${ }^{5}$ AntiCancer Inc., San Diego, CA, U.S.A.; \\ ${ }^{6}$ Department of Surgery, University of California, San Diego, CA, U.S.A.
}

\begin{abstract}
Background/Aim: Dendropanax morbifera (DM) and Commersonia bartramia $(C B)$ are possible candidates for immunotherapy. In this study, the cytotoxicity and chemical sensitization of DM and CB extracts on gynecologic and colon cancers were evaluated. Materials and Methods: The malignant cell lines were cultured and analyzed for cytotoxicity and chemical sensitization. A mouse model was also constructed to make the condition similar to in vivo. Reverse transcriptionpolymerase chain reaction was conducted to determine alterations in drug-resistant genes. Results: The extracts from $D M$ and $C B$ showed specific cytotoxicity to malignant cell lines. $D M$ increased chemical sensitivity to cervical and ovarian cancer, while $C B$ showed improved sensitization to endometrial cancer. The effects of the extracts were confirmed using a mouse model. The extracts induced differences in the expression levels of a number of genes related to drug resistance. Conclusion: $D M$ and $C B$ extracts could be novel agents for immunotherapy and chemical sensitization in gynecologic and colon cancers.
\end{abstract}

Gynecologic and colorectal cancers represent an important global health concern (1). Colon cancer is the third most

This article is freely accessible online.

*These Authors contributed equally to this study.

Correspondence to: Sanghoon Lee, Department of Obstetrics and Gynecology, Korea University Anam Hospital, 73 Inchon-ro, Seongbuk-gu, Seoul 02841, Republic of Korea. Tel: +82 29206773, Fax: +82 29215357, e-mail: mdleesh@gmail.com

Key Words: Chemical sensitivity, cytotoxicity, drug response, Dendropanax, Commersonia. common malignancy in both men and women in the United States (2), and is associated with both genetic and environmental factors. Genetically, it is correlated with familial adenomatous polyposis and hereditary non-polyposis colorectal cancers $(3,4)$. It has also been linked to environmental factors such as obesity, alcohol, and smoking, among others (5). Gynecologic cancers are one of the main causes of death in women (6). In Europe, endometrial cancer is the most common, followed by ovarian and cervical cancers. In the field of endometrial carcinoma, there is no standard screening test but a diagnosis is often made at the early stages because frequent vaginal bleeding is a common symptom. In contrast, ovarian cancer is often only diagnosed at an advanced stage due to lack of screening and asymptomatic disease progression (7). For cervical cancer, the Papanicolaou test has dramatically improved the rates of early diagnosis, and extensive human papillomavirus vaccination programs have markedly decreased the incidence of cervical cancer (8). Despite the different molecular profiles associated with each malignancy, these cancers have poor prognosis with traditional chemotherapy treatments in the more advanced stages of disease (9-11).

Immunotherapy is defined as the treatment of a disease by inducing, enhancing, or suppressing an immune response (12). It is the newest frontier of anticancer therapy and is based on initiating an endogenous immune response against cancer (6). In colon cancer, the combination of immunotherapy and chemotherapy has resulted in increased patient survival and an enhancement of immunologic responses (13). Many clinical trials for immunotherapy are showing promising results with positive antitumor immune responses. Likewise, vaccines have proven to be effective in preventing ovarian cancer (7). A number of preclinical and 
phase I trials are being assessed for the application of immunotherapy in endometrial cancer (14), while several immunotherapies targeting human papilloma virus are under investigation for cervical cancer (15).

Dendropanax morbifera (DM) belongs to the Araliaceae family and has been used as a traditional medicinal plant in the Republic of Korea (16). In a previous study, it was found to reduce the lipid profiles in mice serum in a dosedependent manner (17), and also showed antioxidant and anticancer activities (18). Commersonia bartramia (CB) belongs to the Malvaceae family and is usually found in Australia and Southeast Asia (19). In a previous study, it was found to have a cytotoxic effect on leukemia cell lines (20).

In this study, we evaluated the cytotoxic effect and chemical sensitization properties of DM and CB extracts was evaluated on gynecologic and colon cancers.

\section{Materials and Methods}

Extraction from plants. A total of $1 \mathrm{~kg}$ of dried DM leaves was divided into two five-liter Erlenmeyer flasks, followed by the addition of 3.51 of methanol in each flask. After left at room temperature for $24 \mathrm{~h}$, they were filtered using paper filters to obtain their concentrates. This was followed by the addition of 11 of normal saline and 11 of hexane. After another $24 \mathrm{~h}$, the hexane layer was removed and another layer of 11 of hexane was added for repeat extraction. This process was repeated twice. The CM extract was produced using a similar method. After dividing $1 \mathrm{~kg}$ of dried $\mathrm{CM}$ leaves into two flasks, the same amount of methanol as in the above extraction was added. The flasks were then stored at $50^{\circ} \mathrm{C}$ for 3 days, then filtered using paper filters.

Cell culture. Cell lines of endometrial cancer (SUN-1077), ovarian cancer (SK-OV-3, SNU-840, SNU-8, OVCAR3, Caov3), and colon cancer (HT-29, SNU-C5, HCT 116, SW-480, HCT-15) were cultured using RPMI-1640 medium (Roswell Park Memorial Institute medium; Welgene, Kyungbook, Republic of Korea). The HeLa cell line was cultured in DMEM (Dulbecco's Modified Eagle Medium; Welgene). MEM (Medical Research Council cell strain 5) was used for the culture of MRC-5 (Medical Research Council cell strain 5). All cultures were supplemented with $10 \%$ fetal bovine serum (Welgene) and $1 \%$ antibiotics (100x) including penicillin and streptomycin, at $37^{\circ} \mathrm{C}$ in humidified air and $5 \% \mathrm{CO}_{2}$.

MTT assay. A. Chemical sensitivity profile: The chemical sensitization and cytotoxicity were analyzed using a 3-(4,5Dimethylthiazol-2-yl)-2,5-diphenyl tetrazolium bromide (MTT; Sigma Chemical Co., St. Louis, MO, USA) assay. The detailed methodology of this assay has been described previously $(21,22)$. Briefly, $5 \times 10^{4}$ cells of each HeLa, SUN-1077, SK-OV-3, and HT29 cell line were seeded in 96-well plates in $100 \mu \mathrm{l}$ culture medium. The cells were incubated at $37^{\circ} \mathrm{C}, 5 \% \mathrm{CO}_{2}$ overnight for attachment. As a preliminary study, $20 \mu \mathrm{l}$ of several drugs used for chemotherapy in endometrial cancer, ovarian cancer, cervical cancer, and colon cancer were added, and the mixture was cultured for $72 \mathrm{~h}$. Thereafter, the cells were treated with MTT. After that, all of the medium was aspirated from the wells. The remaining formazan crystals were dissolved in dimethyl sulfoxide (DMSO) and the inhibition rate (IR) was measured at 540/630 nm using a 96-well microplate reader. As a result of this preliminary study, 2 drugs with good sensitivity and 2 drugs with low sensitivity were chosen for the experiment. For the next stage of our study, $20 \mu \mathrm{l}$ of each of the 4 drugs was added to $5 \times 10^{4}$ cells in 96-well plates after resolution in $1 \mathrm{X}$ phosphate buffered saline (PBS) and analyzed using an MTT assay. All experiments were performed more than twice before carrying out a statistical analysis.

B. Cytotoxicity: Vero and MRC-5 cell-lines with same cell count as in chemical sensitivity analysis were seeded in 96 well plates in $100 \mu \mathrm{L}$ culture medium. The cells were incubated at $37^{\circ} \mathrm{C}, 5 \% \mathrm{CO}_{2}$ for $24 \mathrm{~h}$. The extracts from DM and CB were resolved with 1X PBS and added. After $72 \mathrm{~h}$ of culture, the supernatant was removed, and the cells were treated with MTT for cytotoxic analysis. All experiments were performed more than twice before statistical analysis.

C. Chemical sensitization effect of extracts: Here, $5 \times 10^{4}$ cells of each HeLa, SUN-1077, SK-OV-3, and HT-29 cell line were seeded in 96-well plates in $100 \mu \mathrm{l}$ of culture medium and incubated. After removal of the medium, the $\mathrm{DM}$ and $\mathrm{CB}$ extracts were dissolved in $1 \mathrm{X}$ PBS at various concentrations $(1500 \mu \mathrm{g} / \mathrm{ml}, 1000 / \mathrm{ml}, 500$ $\mu \mathrm{g} / \mathrm{ml}, 200 \mu \mathrm{g} / \mathrm{ml} 150 \mu \mathrm{g} / \mathrm{ml}, 100 \mu \mathrm{g} / \mathrm{ml}, 50 \mu \mathrm{g} / \mathrm{ml})$. After $72 \mathrm{~h}$, the supernatant was removed and the cells were treated with MTT for analysis. All experiments were performed more than twice.

D. Animal model: Several ovarian cancer (SK-OV-3, SNU-840, SNU-9, OVCAR3, Caov3) and colon cancer (SNU-C5, HT-29, HCT 116, SW-480, HCT-15) cell lines were cultured in RPMI-1640 medium. Each cell line was cultured in medium including $10 \%$ FBS, then separated from the culture dish using trypsin-EDTA and diluted with PBS at $6 \times 10^{6}$ cells in $0.2 \mathrm{ml}$. These cells were injected subcutaneously to 5 -week-old female nude mice adapted for one week at $23 \pm 3^{\circ} \mathrm{C}$ with a humidity of $55 \pm 15 \%$. They were raised in the same sterile conditions. The tumors were removed when the size reached $250 \mathrm{~mm}^{3}$.

3-Dimensional histoculture drug response assay (3D-HDRA). The cancerous portions of the specimens were minced into pieces of approximately $1 \mathrm{~mm}$ in diameter. Cancer tissues were further cut into $10-\mathrm{mg}$ pieces, weighed on a chemical balance, and placed onto collagen gels, immersed in $1 \mathrm{ml}$ Roswell Park Memorial Institute 1640 (RPMI-1640) medium (Sigma). After incubation for $72 \mathrm{~h}$ at $37^{\circ} \mathrm{C}$ with $5 \% \mathrm{CO}_{2}$, MTT was added to each well. Plates were incubated for another $2 \mathrm{~h}$, the media were removed, and $0.5 \mathrm{ml}$ dimethyl sulfoxide was added to each well to extract MTT formazan. The absorbance was measured using an ELISA reader. The inhibition rate of tumor growth (IR) was calculated using the following equation: IR $(\%)=(1-$ mean absorbance of treated wells per gram of tumor/mean absorbance of control wells per gram of tumor) $\times 100$. In this study, the IR cut-off value for a positive response was previously determined to be $\geq 30 \%(23,24)$.

$R N A$ extraction and reverse transcription-polymerase chain reaction $(R T-P C R)$. RNA was separated from 4 types of cancer cells using Trizol Reagent (RNAiso Plus, Thermo Fisher, MA, USA). $1 \mu \mathrm{g}$ of RNA was used for cDNA synthesis using a superscript first-strand system (Invitrogen, CA, USA). cDNA was diluted for use in RTPCR. The reaction solution contained $4 \mu \mathrm{l}$ of $10 \times$ PCR buffer, 0.2 $\mathrm{mmol} / \mathrm{l}$ of each dNTP, $10 \mathrm{pmol}$ of each primer, $2.5 \mathrm{U}$ of Taq DNA polymerase (Takara; Japan) and $4 \mu \mathrm{l}$ of cDNA. The real-time quantitative analysis was performed using a Light cycler 2.0 instrument (Roche, Mannheim, Germany). 


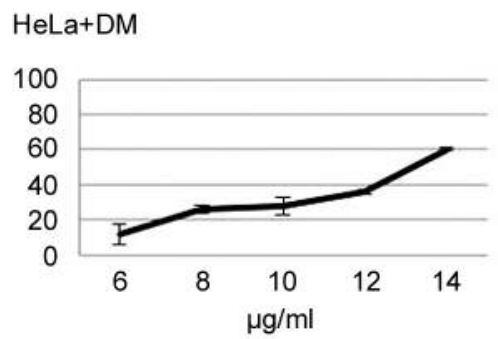

SNU-1077+DM

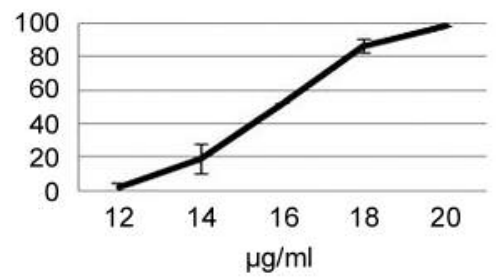

\section{SK-OV-3+DM}

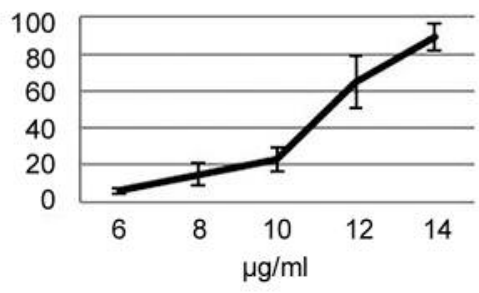

$\mathrm{HeLa}+\mathrm{CB}$
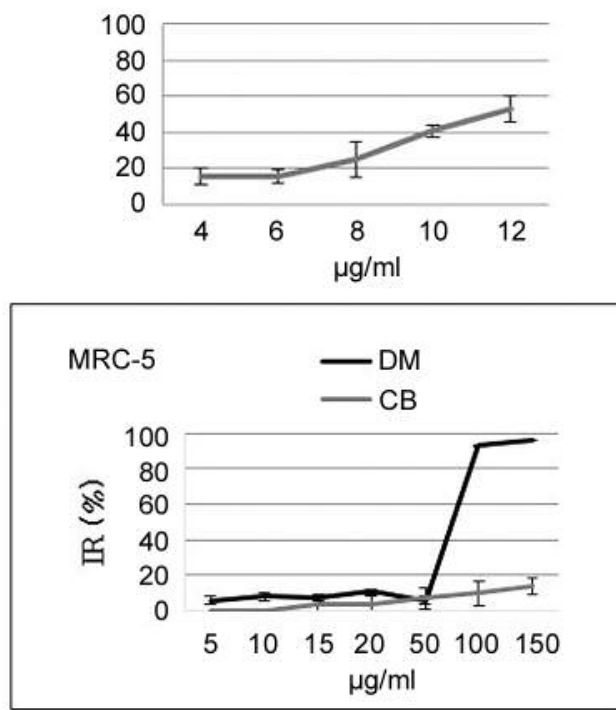

HT-29+DM

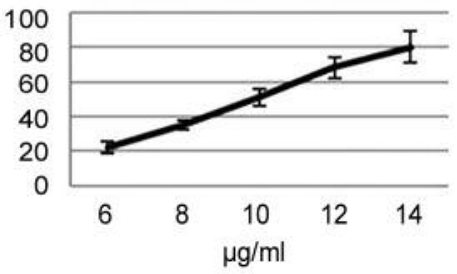

SNU-1077+CB

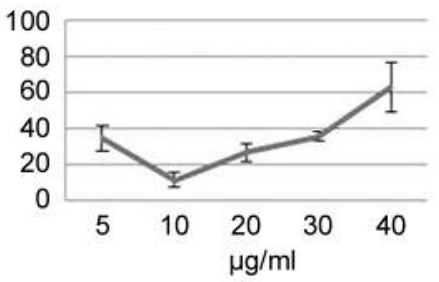

SK-OV-3+CB

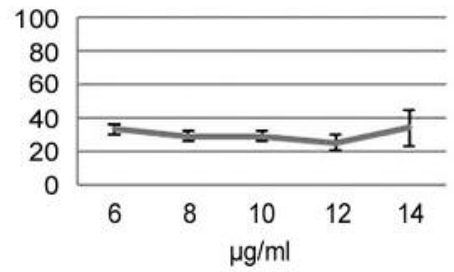

HT-29+CB

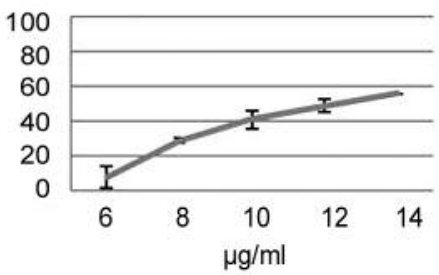

Figure 1. Cytotoxic effects of extracts of Dendropanax morbifera and Commersonia bartramia. The extracts showed a more cytotoxic effect to cancer cell lines than MRC-5.

Statistical analysis. Statistical analysis was performed using a Kruskal-Wallis rank test, and a Mann-Whitney $U$-test was used to calculate the $p$-value and to compare the immuno-histochemistry differences of the groups. Statistical SPSS software package version 20.0 (SPSS Inc, Chicago, IL, USA) was used to analyze the data. Differences were considered statistically significant at $p<0.05$.

\section{Results}

Chemical sensitivity profiles. For the chemical sensitivity profiles of the chemical agents, docetaxel and paclitaxel showed an IR over $80 \%$ for SK-OV-3 and HeLa cell-lines. Carboplatin and cisplatin showed an IR of less than $25 \%$. On the other hand, docetaxel and paclitaxel had an IR over $30 \%$; carboplatin and cisplatin had an IR of less than $20 \%$ for SNU-1077. Otherwise, fluorouracil, oxaliplatin, and irinotecan showed an IR of $56 \%$, $55 \%$, and $28 \%$ IR for HT-29, respectively.

Cytotoxicity of extracts of Dendropanax morbifera and Commersonia bartramia. The cytotoxic activity of the DM and $\mathrm{CB}$ extracts was studied against cultured MRC-5 (normal), SK-OV-3, HeLa, SNU-1077, and HT-29 cell lines using MTT assays. The MRC-5 cell line was subjected to increasing doses of extracts ranging from 5 to $150 \mu \mathrm{g} / \mathrm{ml}$ (Figure 1). DM showed cytotoxicity of more than $93 \%$ at doses $>100 \mu \mathrm{g} / \mathrm{ml}$, and $6 \sim 11 \%$ at doses lower than $50 \mu \mathrm{g} / \mathrm{ml}$. CB extracts showed $10 \%$ cytotoxicity at doses $>100 \mu \mathrm{g} / \mathrm{ml}$, and $4 \sim 6 \%$ at doses ranging from $15 \sim 50 \mu \mathrm{g} / \mathrm{ml}$. The lower doses of DM and CB extracts caused toxicity to cancer cells compared to the doses of MRC-5, indicating a degree of specificity for malignant cell lines.

Chemical sensitization effect on cancer cell lines. To explore the role of $\mathrm{DM} / \mathrm{CB}$ in the regulation of chemosensitivity of human cancer cells, the drug sensitivity of cancer cells was compared with that of control cells, using an MTT assay. Each of the cytotoxic agents at various concentrations (reference dose from previous chemosensitivity test) were mixed in a 1:1 ratio with 5 or $10 \mu \mathrm{g} / \mathrm{ml} \mathrm{DM} / \mathrm{CB}$ extracts before treating the HeLa cell line (cervical cancer). The IR was found to increase more than 1.5 times when the DM extracts were added to carboplatin (Figure 2). Cisplatin, paclitaxel, and docetaxel showed a similar chemical sensitization effect as DM and no 


\section{A. Carboplatin (CBP)}

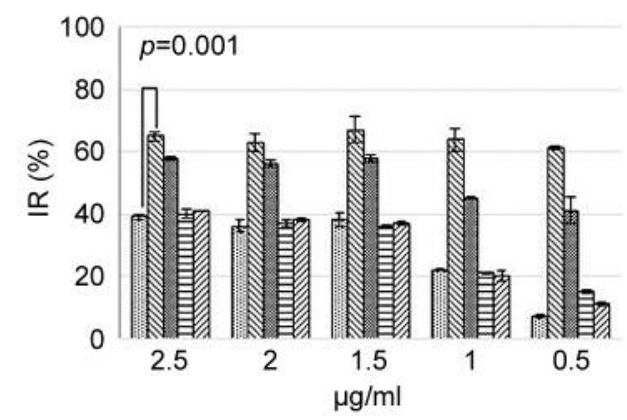

\section{B. Cisplatin (CDDP)}

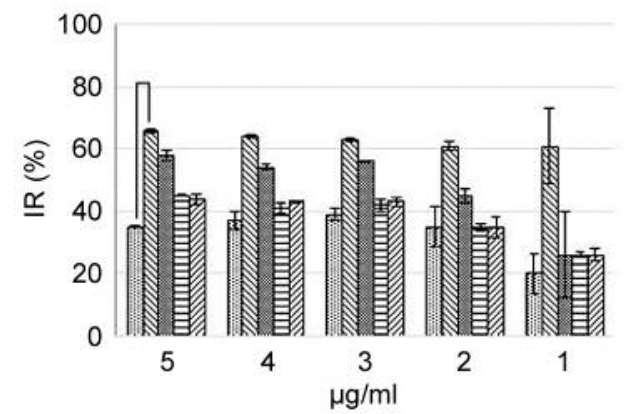

\section{Docetaxel (DTAX)}
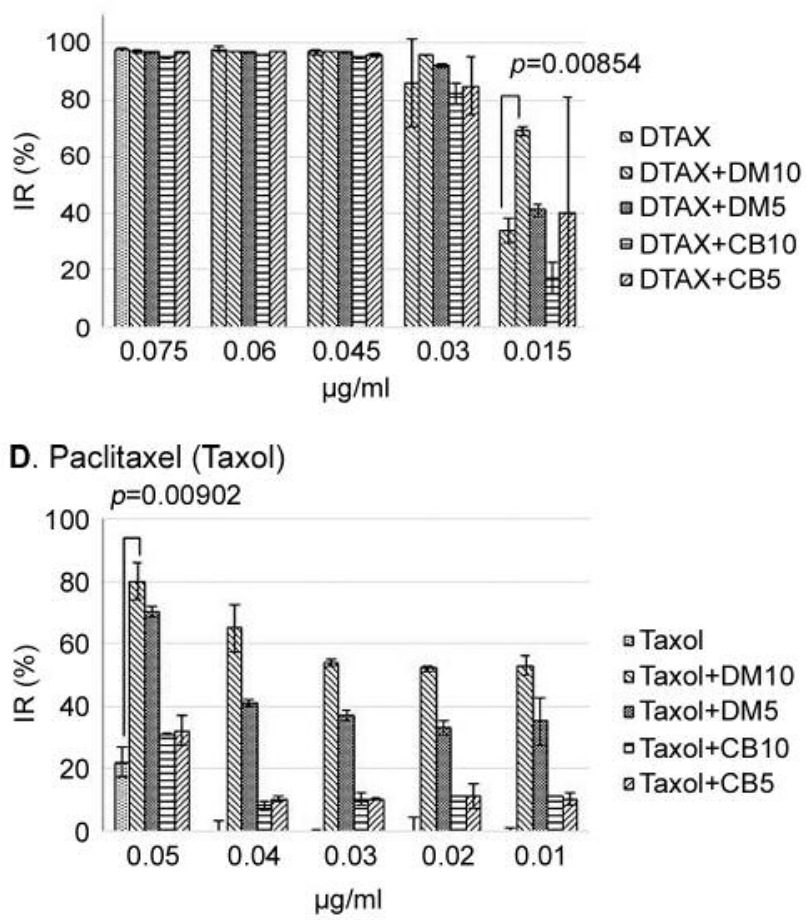

Figure 2. Chemical sensitization effect of Dendropanax morbifera and Commersonia bartramia on HeLa cell line. IR was increased by Dendropanax morbifera, but not by Commersonia bartramia.

effect was confirmed with $\mathrm{CB}$. With the SK-OV-3 cell line of ovarian cancer, carboplatin, docetaxel, paclitaxel, and cisplatin also showed increased sensitivity to DM, but not to $\mathrm{CB}$ (Figure 3). However, the drugs showed the opposite result when they were added to the SNU-1077 cell line (endometrial cancer). None of the agents were sensitized with DM but a remarkable change in IR was observed when they were mixed with CB (Figure 4). Finally, HT-29 cells (colon cancer) were treated with three different drugs. 5-fluorouracil and oxaliplatin showed moderate sensitization only with $\mathrm{CB}$, but irinotecan showed dramatic changes in its IR when it was mixed with DM and CB (Figure 5).

In vivo evaluation using 3D-HDRA. 3D-HDRA was used to evaluate the cytotoxicity and chemosensitivity of DM/CB in in vivo conditions. Several types of ovarian cancer and colon cancer cell lines were cultured and implanted in mice, and the resected tumors were analyzed by 3 D-HDRA. CB showed chemical sensitization effects with irinotecan on most types of colon cancer cell lines, and DM increased the sensitivity of ovarian cancer cell lines to paclitaxel (Figure 6).

Analysis of drug-resistant gene expression by $D M / C B$. The $\mathrm{DM} / \mathrm{CB}$ extracts were added to various cancer cell lines using a multidrug resistance diagnostic kit (Drugsporter; Chosun University, Republic of Korea) (Table I). In HeLa cells, DM caused a reduction in the expression of 11 genes related to drug resistance and upregulation of the expression of 1 gene, while $\mathrm{CB}$ decreased the expression of 8 genes and increased the expression of 2 genes. There were also several alterations of drug resistant genes in other cell lines (SK-OV3, SNU-1077, HT-29).

\section{Discussion}

Most chemotherapeutic agents act by inducing apoptosis in cancer cells, which affects their sensitivity to anticancer drugs (25). In a previous study, DM extracts showed a cytotoxicity of up to $26 \%$ on normal hepatocytes, and over $50 \%$ on various cancer cell lines (26). These extracts are considered to have selective toxic effects on malignant cells. In another study, DM inhibited cell proliferation of the U937 cell line (leukemia) and induced apoptosis via intrinsic and extrinsic pathways (27).

In this study, DM and CB showed a greater cytotoxic effect on four types of cancer cell lines compared to normal cell lines. The specific molecular sensitization effects of the $\mathrm{DM}$ and $\mathrm{CB}$ extracts on diverse chemotherapeutic agents was 


\section{A. Carboplatin (CBP)}

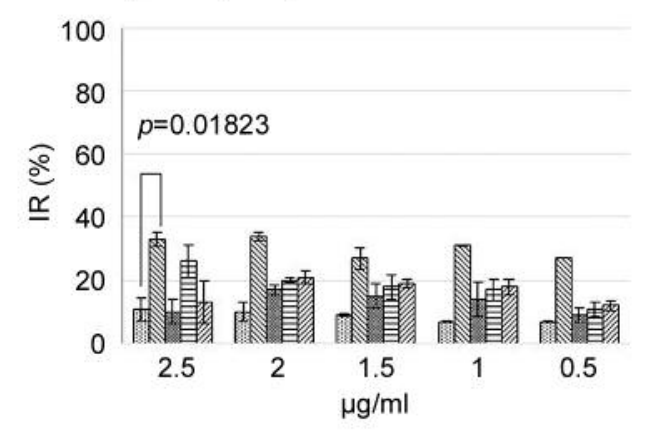

B. Cisplatin (CDDP)

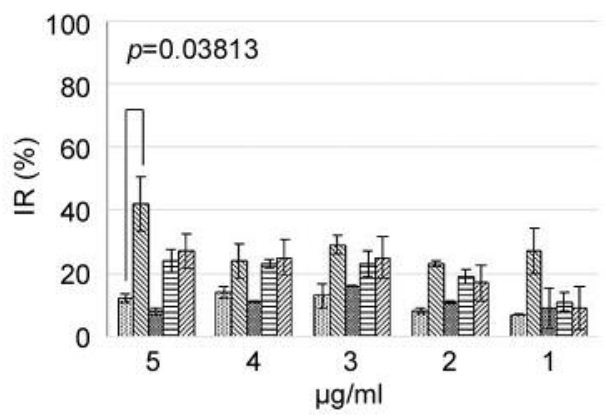

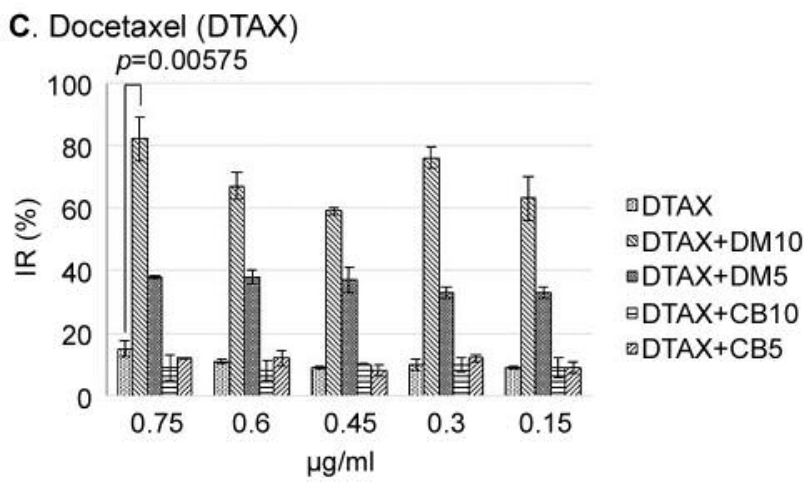

D. Paclitaxel (Taxol)

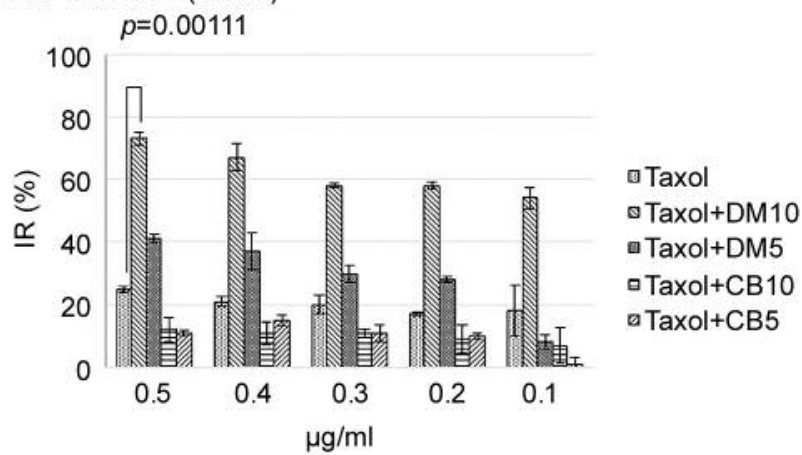

Figure 3. Chemical sensitization effect of Dendropanax morbifera and Commersonia bartramia on SK-OV-3 cell line. Dendropanax raised IR, but Commersonia did not.

A. Carboplatin (CBP)

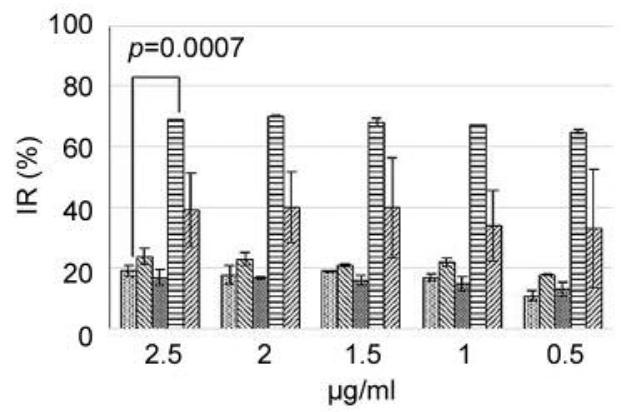

B. Cisplatin (CDDP)

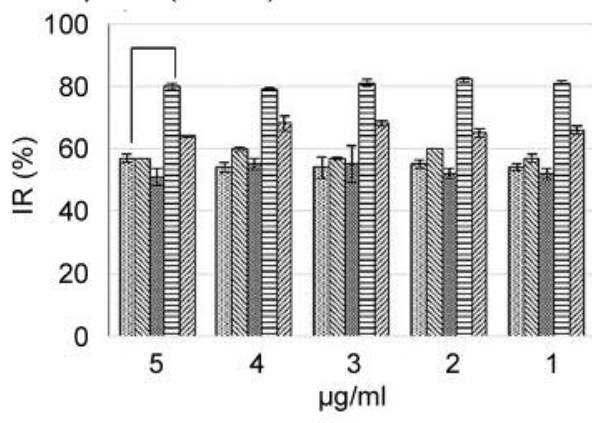

$\square C D D P$ - $C D D P+D M 10$ $\because C D D P+D M 5$ $\because \mathrm{CDDP}+\mathrm{CB} 10$ - CDDP+CB5
${ }^{\square C B P}$ -CBP+DM5 $\mathrm{BCBP}+\mathrm{CB} 10$ - $\mathrm{CBP}+\mathrm{CB} 5$

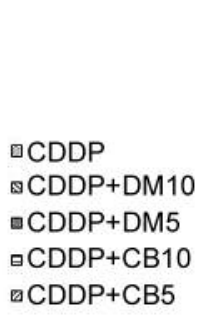

$\square C B P$ \& $C B P+D M 10$ - CBP+DM5 $\because \mathrm{CBP}+\mathrm{CB} 10$ - $\mathrm{CBP}+\mathrm{CB} 5$

- $C D D P$ $\triangle \mathrm{CDDP}+\mathrm{DM} 10$ - CDDP+DM5 ${ }_{-} \mathrm{CDDP}+\mathrm{CB} 10$ - $C D D P+C B 5$

\section{Docetaxel (DTAX)}

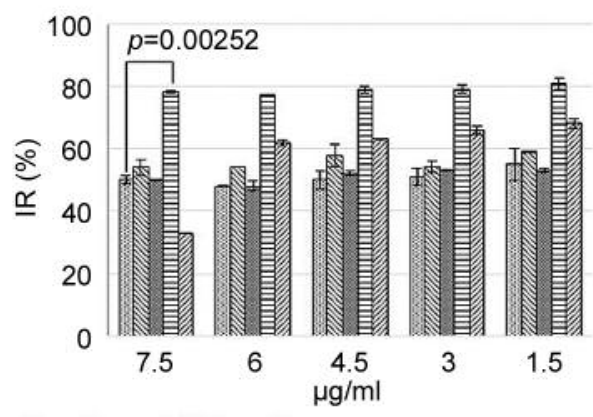

DDTAX $\triangle D T A X+D M 10$ $\triangle D T A X+D M 5$ BDTAX+CB10 DTAX+CB5
D. Paclitaxel (Taxol)

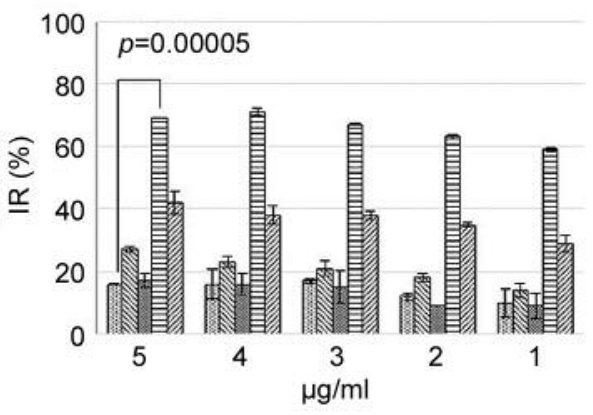

- Taxol

๑ Taxol+DM10

- Taxol+DM5

$\because$ Taxol+CB10

ฉ $\mathrm{Taxol}+\mathrm{CB} 5$

Figure 4. Chemical sensitization effect of Dendropanax morbifera and Commersonia bartramia on SNU-1077 cell line. Inhibition rate was remarkably increased only by Commersonia bartramia. 

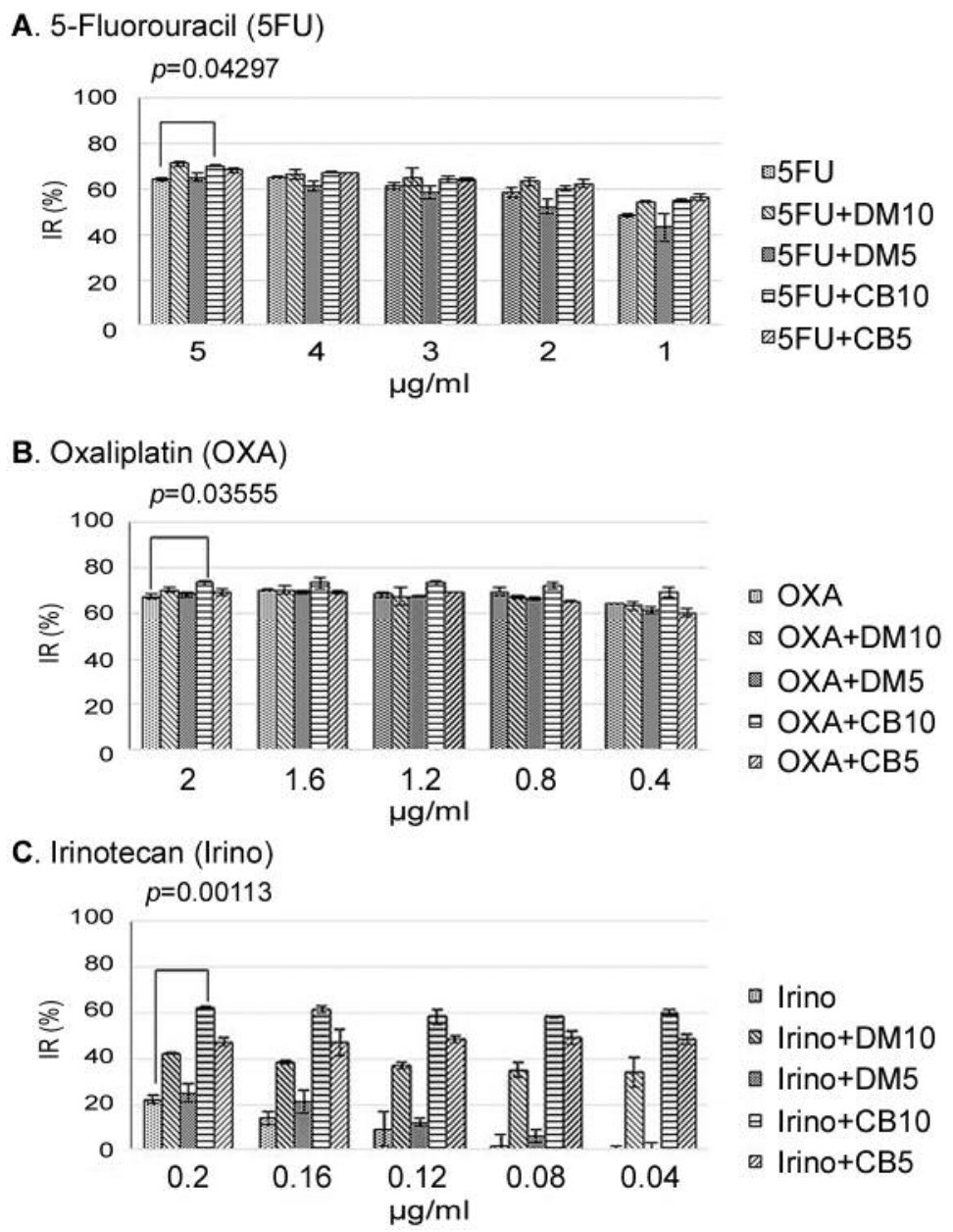

Figure 5. Chemical sensitization effect of Dendropanax morbifera and Commersonia bartramia on HT-29 cell line. Commersonia showed significant changes in its inhibition rate.

confirmed. DM showed a dose-dependent sensitization to all agents tested on HeLa, while CB had no effect. SNU-1077 was susceptible to $\mathrm{CB}$ but not to DM. In the SK-OV-3 cell line, DM showed a high inhibitory function when it was added to docetaxel and paclitaxel. However, the sensitization decreased with lower doses $(5 \mu \mathrm{g} / \mathrm{ml})$ of DM, suggesting that the chemical sensitization is dependent on the concentration of anticancer drugs. The IR was diminished when CB was mixed with paclitaxel, suggesting that $\mathrm{CB}$ suppresses the reaction of paclitaxel in SK-OV-3. In colon cancer cell lines, fluorouracil and oxaliplatin were not affected by DM and $\mathrm{CB}$, while irinotecan showed increased sensitivity to both $\mathrm{DM}$ and $\mathrm{CB}$.

Paclitaxel is used for the treatment of carcinomas in the ovaries, breasts, lungs, head, and neck, and induces polymerization of microtubules irreversibly, which is also a target of vinca alkaloids (28). The action of irinotecan occurs via the topoisomerase I inhibitor, which is then inactivated by glucuronidation by uridine diphosphate glucuronosyltransferase $1 \mathrm{~A} 1$, and leads to the inhibition of DNA replication and transcription (29). The mechanism of action of DM and CB is not well understood, but the resulting apoptosis is considered to be the main stream of action as with most agents.

Since the characteristics and genetic manifestations of cancer cells are affected by the method and condition of the cell culture, the interactions between cancer cells and normal cells are important. A 3D culture is more similar to the in vivo environment than a $2 \mathrm{D}$ culture, and therefore can yield results that are closer to the drug responses seen in clinical trials (30). 3D-HDRA is a type of 3D culture that is being used to determine the efficacy of chemotherapeutic agents in individuals by identifying their chemical sensitization profiles (31). Here, a mouse model was constructed using ovarian and colon cancer cell lines to obtain cancer tissues 


\section{A. Colon cancer}

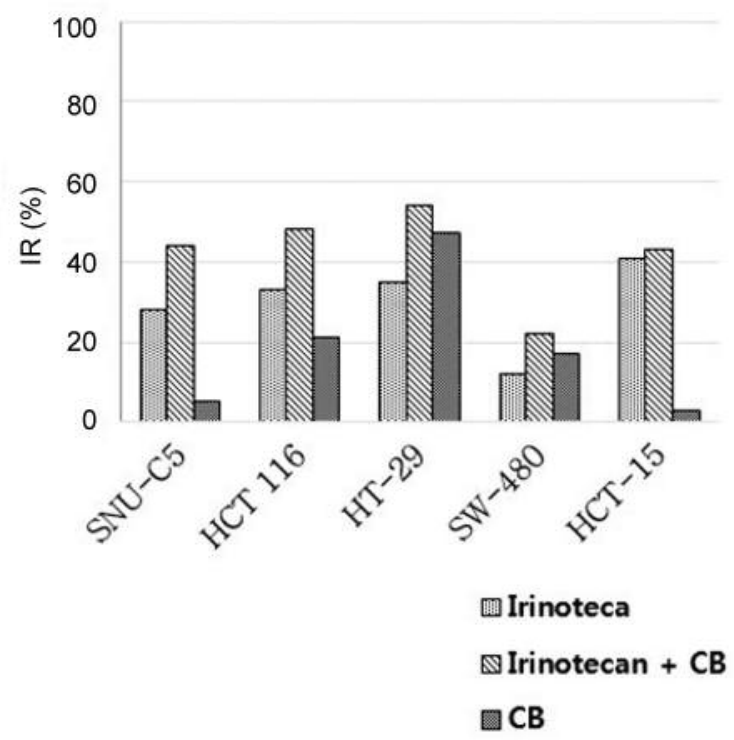

B. Ovarian cancer

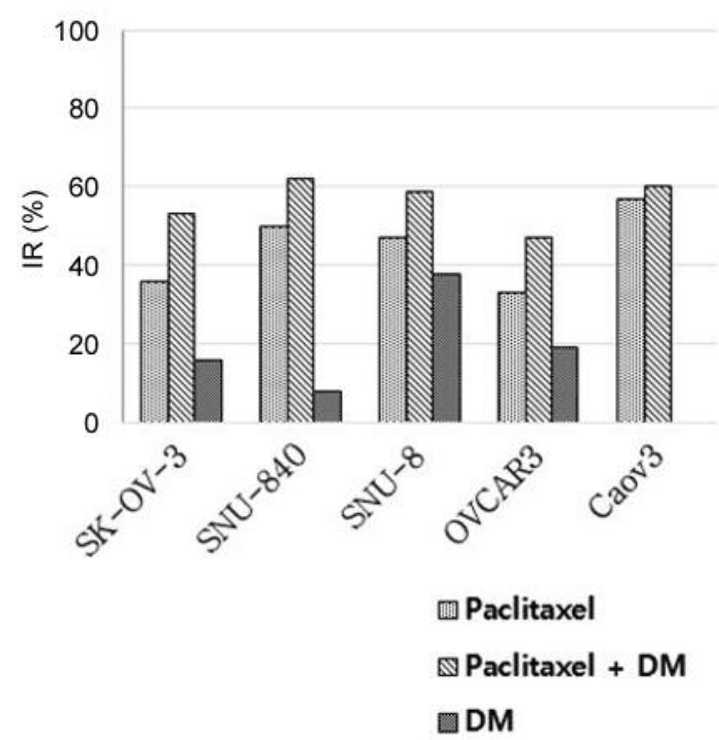

Figure 6. Chemosensitization evaluation of extracts using 3D-HDRA.

Table I. Analysis of drug-resistant gene expression by $D M / C B$.

\begin{tabular}{|c|c|c|c|c|c|c|c|c|c|c|c|c|c|}
\hline & & \multicolumn{3}{|c|}{ Endometrial cancer } & \multicolumn{3}{|c|}{ Ovarian cancer } & \multicolumn{3}{|c|}{ Cervical cancer } & \multicolumn{3}{|c|}{ Colon cancer } \\
\hline & & SNU-1077 & $\begin{array}{c}\text { SNU-1077 } \\
+ \text { DM }\end{array}$ & $\begin{array}{l}\text { SNU-1077 } \\
+ \text { CB }\end{array}$ & SK-OV-3 & $\begin{array}{c}\text { SK-OV-3 } \\
+ \text { DM }\end{array}$ & $\begin{array}{l}\text { SK-OV-3 } \\
+ \text { CB }\end{array}$ & HeLa & $\begin{array}{l}\text { HeLa } \\
+ \text { DM }\end{array}$ & $\begin{array}{l}\mathrm{HeLa} \\
+\mathrm{CB}\end{array}$ & HT-29 & $\begin{array}{c}\text { HT-29 } \\
+ \text { DM }\end{array}$ & $\begin{array}{c}\text { HT- } 29 \\
+ \text { CB }\end{array}$ \\
\hline GAPDH & & 0.160 & 0.160 & 0.160 & 0.200 & 0.200 & 0.200 & 0.200 & 0.200 & 0.200 & 0.115 & 0.115 & 0.115 \\
\hline BCRP & (ABCG2) & & & & & & & 0.275 & 0.045 & & 0.130 & 0.347 & 0.123 \\
\hline MRP1 & $(\mathrm{ABCC} 1)$ & 3.844 & 3.405 & 0.615 & 1.800 & 1.862 & 1.616 & 3.775 & 3.240 & 0.948 & 0.696 & 1.190 & 0.985 \\
\hline LRP & (MVP) & 3.313 & 3.321 & 3.380 & 4.525 & 1.923 & 5.216 & 2.800 & 2.071 & 1.354 & 1.478 & 1.303 & 1.464 \\
\hline WND & (ATP7B) & & & & & & & & & & & 0.008 & \\
\hline CFTR & $(\mathrm{ABCC} 7)$ & 0.313 & 0.553 & & & & & & & & 0.435 & 0.440 & 0.479 \\
\hline MRP8 & $(\mathrm{ABCC} 11)$ & 0.125 & & & & & 0.257 & & & & & & 0.178 \\
\hline ENT1 & (SLC29A1) & 0.063 & & & & & & & & & & & \\
\hline CNT1 & (SLC25A1) & 0.031 & 0.027 & & 0.175 & 0.285 & 0.147 & 0.025 & 0.015 & 0.037 & & 0.274 & 0.082 \\
\hline SUR2 & $(\mathrm{ABCC} 9)$ & 0.188 & 0.056 & 0.088 & 0.100 & 0.062 & 0.074 & 0.050 & 0.059 & 0.037 & 0.261 & 0.020 & 0.027 \\
\hline CTR1 & (SLC31A1) & 0.469 & 0.083 & & 0.100 & 0.285 & 0.036 & 0.150 & 0.029 & & & 0.085 & 0.150 \\
\hline MRP4 & (ABCC4) & 1.406 & 0.498 & 0.044 & 0.625 & 0.869 & 0.184 & 0.475 & 0.104 & 0.013 & 0.261 & 0.161 & 0.780 \\
\hline MDR3 & (ABCB4) & 0.063 & & & & & & & & & & & \\
\hline $\mathrm{ABC} 8$ & (ABCG1) & 0.156 & & & 0.025 & 0.062 & & 1.400 & 0.622 & 0.493 & 0.391 & 0.702 & 0.670 \\
\hline MRP6 & (ABCC6) & 0.188 & & & & & & & & & & & \\
\hline MRP3 & $(\mathrm{ABCC} 3)$ & 1.094 & 0.138 & 0.044 & 0.350 & 0.577 & 0.331 & 0.375 & 0.266 & 0.086 & 0.348 & 0.638 & 0.493 \\
\hline ABCB5 & (ABCB5) & 0.250 & & & & 0.015 & & & & & & & \\
\hline MRP7 & (ABCC10) & 0.719 & 0.305 & 0.175 & 0.225 & 0.223 & 0.293 & 0.050 & 0.029 & & & 0.044 & 0.123 \\
\hline MRP5 & $(\mathrm{ABCC} 5)$ & 4.781 & 4.180 & 0.966 & 1.650 & 1.985 & 0.221 & 0.600 & 0.429 & 0.086 & 0.087 & 0.157 & 0.164 \\
\hline MRP2 & $(\mathrm{ABCC} 2)$ & 0.406 & 0.083 & & 0.050 & 0.146 & & 0.025 & & & & 0.020 & \\
\hline $\mathrm{ABC} 3$ & (ABCA3) & & & & & & & 0.375 & & & & & \\
\hline MDR1 & (ABCB1) & 0.344 & 0.166 & 0.088 & 1.050 & 1.154 & 1.616 & 0.050 & 0.192 & 0.123 & 0.043 & 0.065 & \\
\hline ENT2 & (SLC29A2) & 0.375 & & & & 0.031 & & & & & & & \\
\hline $\mathrm{ABCA} 2$ & (ABCA2) & 0.563 & 0.249 & 0.088 & 0.325 & 0.338 & 0.367 & 0.300 & 0.178 & 0.086 & 0.130 & 0.573 & 0.548 \\
\hline CNT2 & (SLC28A2) & 0.281 & 0.111 & & & & & & & & & 0.016 & 0.013 \\
\hline
\end{tabular}


with which to evaluate cytotoxicity and chemical sensitization. All ovarian cancer cells except Caov3 showed an increased IR with DM in combination with paclitaxel, and most colon cancer cells were more sensitive to $\mathrm{CB}$ combined with irinotecan. This suggests that sensitivity can vary according to the type of cell line. Although the experiment was repeated 5 times, the number of samples was not enough to deduce the exact effect of the extracts, and therefore would require further analysis using 3D-HDRA.

Membrane transporters maintain cellular homeostasis by importing nutrients and exporting toxins. Transporters also have roles in drug response, serving as drug targets and setting drug levels (32). In this study, the gene expression of specific transporters was analyzed by normalizing with glyceraldehyde 3-phosphate dehydrogenase. When DM was applied to HeLa, the expression of genes resistant to cisplatin and carboplatin (ABCC1, SLC31A1, ABCC3) decreased, which is concordant to the increased IR by DM to these drugs. The genes expressing resistance to paclitaxel and docetaxel (ABCC10 and $\mathrm{ABCB} 1$ ) also decreased, and the increased IR with improved sensitivity could be an explanation. Januchowski et al. reported that the ATPbinding cassette family protein is related to the expression of the ABCB1 gene in more than half of drug-resistant cancers (33). This is because DM suppresses the expression of specific transporter genes. In SNU-1077, CB was related with impairment of carboplatin resistance genes (SLC31A1), paclitaxel resistance genes (ABCC1, ABCC10, and ABCB1), and cisplatin resistance genes (SLC31A1, ABCC3). This is reflected by the increased IR in SNU-1077 after the application of the CB extract.

Nakayama et al. reported an increased expression of ABCB1, ABCC1, ABCC2, MVP, ABCG2, and ATP7B genes in patients with untreated ovarian cancer, and found a specific relation between ATP7B and cisplatin resistance (34). Treatment of SK-OV-3 cell line with DM extracts resulted in inhibition of MVP gene expression. On the other hand, the genes expressing resistance to docetaxel did not show any change with DM, but this does not correspond to the increases in IR. As such, there could be another mechanism, such as a synergistic effect, between DM and docetaxel. The sensitization of CB with irinotecan in HT-29 cells also showed a discordance with the gene analysis. The ABCC2 gene was not altered by CB. According to a previous study, some errors could occur in evaluating the therapeutic effect in colon cancer due to resistant genes including $\mathrm{ABCB} 1, \mathrm{ABCC} 1$, and $\mathrm{ABCG} 2$ (35), so further studies are necessary to confirm the mechanism and regulation of drug-resistant gene expression. The above results suggest that $\mathrm{DM}$ and $\mathrm{CB}$ extracts could play important roles in reducing the expression of transporter genes that exist on the cellular membrane and therefore to improve sensitivity to specific anticancer drugs.
A limitation of this study is that the results were deducted mainly from in vitro experiments, so the exact efficacy of the extracts should be evaluated using fresh tissues to identify actual functions. Therefore, an animal model was constructed to resemble in vivo condition. A significant increase in chemosensitivity was also observed in vivo. Additional work using different agents is ongoing in our institution.

Our study is significant for two reasons. Above all, this is the first study evaluating the cytotoxic effect of DM and CB in gynecologic and colorectal cancers. It could lead to the identification of a new target therapy for these malignancies or other cancers. Secondly, the experimental design of the study was well established and conducted deliberately. The cytotoxicity and sensitization of materials were evaluated step by step with various concentrations, and this could determine the dose dependent activity of the materials.

In conclusion, DM and $\mathrm{CB}$ extracts could be used as anticancer drugs and chemical sensitization agents for gynecologic and colon cancers. Drug resistance in these cancers is still an important obstacle in the success of chemotherapy to which this study might provide a novel therapeutic strategy. Further studies are needed in order to identify their exact mechanism of action and to determine their appropriate clinical application.

\section{Acknowledgements}

This study was supported by the National Research Foundation of Korea Grant funded by the Korean Government (NRF2016R1C1B3015250) and Korea University Grant (K1620191).

\section{References}

1 Steliarova-Foucher E, O'Callaghan M, Ferlay J, Masuyer E, Rosso S, Forman D, Bray F and Comber H: The European Cancer Observatory: A new data resource. Eur J Cancer 51(9): 1131-1143, 2015.

2 Ferlay J, Shin HR, Bray F, Forman D, Mathers C and Parkin DM: Estimates of worldwide burden of cancer in 2008: GLOBOCAN 2008. Int J Cancer 127(12): 2893-2917, 2010.

3 Lynch HT, Lynch JF, Lynch PM and Attard T: Hereditary colorectal cancer syndromes: molecular genetics, genetic counseling, diagnosis and management. Fam Cancer 7(1): 2739, 2008.

4 Stoffel EM and Boland CR: Genetics and genetic testing in hereditary colorectal cancer. Gastroenterology 149(5): 11911203 e2, 2015.

5 Jung GR, Kim KJ, Choi CH, Lee TB, Han SI, Han HK and Lim SC: Effect of betulinic acid on anticancer drug-resistant colon cancer cells. Basic Clin Pharmacol Toxicol 101(4): 277-285, 2007.

6 Ventriglia J, Paciolla I, Pisano C, Cecere SC, Di Napoli M, Tambaro R, Califano D, Losito S, Scognamilgio G, Setola SV, Arenare L, Pignata S and Pepa CD: Immunotherapy in ovarian, endometrial and cervical cancer: State of the art and future perspectives. Cancer Treat Rev 59: 109-116, 2017. 
7 Zsiros E, Tanyi J, Balint K and Kandalaft LE: Immunotherapy for ovarian cancer: recent advances and perspectives. Curr Opin Oncol 26(5): 492-500, 2014.

8 OECD, Health at a Glance 2013: OECD Indicators. OECD Publishing. http://dx.doi.org/10.1787/health_glance-2013-en, 2013.

9 Figueredo A, Coombes ME and Mukherjee S: Adjuvant therapy for completely resected stage II colon cancer. Cochrane Database Syst Rev (3): CD005390, 2008.

10 Van Driel WJ, Koole SN, Sikorska K, Schagen van Leeuwen JH, Schreuder HWR, Hermans RHM, de Hingh IHJT, van der Velden J, Arts HJ, Massuger LFAG, Aalbers AGJ, Verwaal VJ, Keiffer JM, van de Vijver KK, van Tinteren H, Aaronson NK and Sonke GS: Hyperthermic Intraperitoneal Chemotherapy in Ovarian Cancer. N Engl J Med 378(3): 230-240, 2018.

11 Eskander RN and Tewari KS: Chemotherapy in the treatment of metastatic, persistent, and recurrent cervical cancer. Curr Opin Obstet Gynecol 26(4): 314-321, 2014.

12 Lloyd KO: Carbohydrate vaccines for the immunotherapy of cancer. Drug News Perspect 13(8): 463-470, 2000.

13 Wang ZX, Cao JX, Liu ZP, Cui YX, Li CY, Li D, Zhang XY, Liu JL and Li JL: Combination of chemotherapy and immunotherapy for colon cancer in China: a meta-analysis. World J Gastroenterol 20(4): 1095-1106, 2014.

14 Longoria TC and Eskander RN: Immunotherapy in endometrial cancer - an evolving therapeutic paradigm. Gynecol Oncol Res Pract 2: 11, 2015.

15 Eskander RN and Tewari KS: Immunotherapy: an evolving paradigm in the treatment of advanced cervical cancer. Clin Ther 37(1): 20-38, 2015.

16 Wang C, Mathiyalagan R, Kim YJ, Castro-Aceituno V, Singh P, Ahn S, Wang D and Yang DC: Rapid green synthesis of silver and gold nanoparticles using Dendropanax morbifera leaf extract and their anticancer activities. Int $\mathrm{J}$ Nanomedicine 11: 36913701, 2016.

17 Chung IM, Kim MY, Park WH and Moon HI: Antiatherogenic activity of Dendropanax morbifera essential oil in rats. Pharmazie 64(8): 547-549, 2009.

18 Hyun TK, Kim MO, Lee H, Kim Y, Kim E and Kim JS: Evaluation of anti-oxidant and anti-cancer properties of Dendropanax morbifera Leveille. Food Chem 141(3): 1947-1955, 2013.

19 Wilkins CF and Whitlock BA: A revision of Commersonia including Rulingia (Malvaceae s.l. or Byttneriaceae). Australian Systematic Botany 24(5): 226, 2011.

20 Chung HS: Anticancer effect of plant-derived extract: Commersonia bartramia in breast cancer. University of Chosun, Gwangju, Republic of Korea, 2016.

21 Carmichael J, DeGraff WG, Gazdar AF, Minna JD and Mitchell JB: Evaluation of a tetrazolium-based semiautomated colorimetric assay: assessment of chemosensitivity testing. Cancer Res 47(4): 936-942, 1987.

22 Hayon T, Dvilansky A, Shpilberg O and Nathan I: Appraisal of the MTT-based assay as a useful tool for predicting drug chemosensitivity in leukemia. Leuk Lymphoma 44(11): 19571962, 2003.

23 Kim JC, Kim DD, Lee YM, Kim TW, Cho DH, Kim MB, Ro SG, Kim SY, Kim YS and Lee JS: Evaluation of novel histone deacetylase inhibitors as therapeutic agents for colorectal adenocarcinomas compared to established regimens with the histoculture drug response assay. Int J Colorectal Dis 24(2): 209218, 2009.
24 Kim JC, Shin ES, Kim CW, Roh SA, Cho DH, Na YS, Kim TW, Kim MB, Hyun YL, Ro SG, Kim SY and Kim YS: In vitro evaluation of histone deacetylase inhibitors as combination agents for colorectal cancer. Anticancer Res 29(8): 3027-3034, 2009.

25 Lee JW, Kim KS, An HK, Kim CH, Moon HI and Lee YC: Dendropanoxide induces autophagy through ERK1/2 activation in MG-63 human osteosarcoma cells and autophagy inhibition enhances dendropanoxide-induced apoptosis. PLoS One 8(12): e83611, 2013.

26 Lee SH, Lee HS, Park YS, Hwang B, Kim JH and Lee HY: Screening of immune activation activities in the leaves of Dendropanax morbifera Lev. Medicinal Crop Sci 10(2): 7, 2002.

27 Lee JW, Park C, Han MH, Hong SH, Lee TK, Lee SH, Kim GY and Choi YH: Induction of human leukemia U937 cell apoptosis by an ethanol extract of Dendropanax morbifera Lev. through the caspase-dependent pathway. Oncology Reports 30(3): 12311238, 2013.

28 Saville MW, Lietzau J, Pluda JM, Feuerstein I, Odom J, Wilson WH, Humphrey RW, Feigel E, Steinberg SM, Broder S, Yarchoan R, Odom J and Feuerstein I: Treatment of HIVassociated Kaposi's sarcoma with paclitaxel. Lancet 346(8966): 26-28, 1995.

29 Pommier Y: Drugging topoisomerases: lessons and challenges. ACS Chem Biol 8(1): 82-95, 2013.

30 Roberts GC, Morris PG, Moss MA, Maltby SL, Palmer CA, Nash CE, Smart E, Holliday DL and Speirs V: An Evaluation of matrix-containing and humanised matrix-free 3-dimensional cell culture systems for studying breast cancer. PLoS One 11(6): e0157004, 2016.

31 Tanino H, Oura S, Hoffman RM, Kubota T, Furukawa T, Arimoto J, Yoshimasu T, Hirai I, Bessho T, Suzuma T, Sakurai $\mathrm{T}$ and Naito Y: Acquisition of multidrug resistance in recurrent breast cancer demonstrated by the histoculture drug response assay. Anticancer Res 21(6A): 4083-4086, 2001.

32 Leabman MK, Huang CC, DeYoung J, Carlson EJ, Taylor TR, de la Cruz M, Johns SJ, Stryke D, Kawamoto M, Urban TJ, Kroetz DL, Ferrin TE, Clark AG, Risch N, Herskowitz I and Giacomini KM: Natural variation in human membrane transporter genes reveals evolutionary and functional constraints. Proc Natl Acad Sci USA 100(10): 5896-5901, 2003.

33 Januchowski R, Wojtowicz K, Andrzejewska M and Zabel M: Expression of MDR1 and MDR3 gene products in paclitaxel-, doxorubicin- and vincristine-resistant cell lines. Biomed Pharmacother 68(1): 111-117, 2014.

34 Nakayama K, Kanzaki A, Ogawa K, Miyazaki K, Neamati N and Takebayashi Y: Copper-transporting P-type adenosine triphosphatase (ATP7B) as a cisplatin based chemoresistance marker in ovarian carcinoma: comparative analysis with expression of MDR1, MRP1, MRP2, LRP and BCRP. Int J Cancer 101(5): 488-495, 2002.

$35 \mathrm{Hu} \mathrm{T}$, Li Z, Gao CY and Cho $\mathrm{CH}$ : Mechanisms of drug resistance in colon cancer and its therapeutic strategies. World $\mathrm{J}$ Gastroenterol 22(30): 6876-6889, 2016.
Received May 2, 2018

Revised May 20, 2018

Accepted May 23, 2018 